\title{
The Impact Of The Principles Of Accounting Experience On Student Preparation For Intermediate Accounting
}

Linda G. Carrington, Ph.D., Sam Houston State University, USA

\begin{abstract}
Both students and instructors alike will generally agree that intermediate accounting courses are among the most difficult and demanding in an accounting or finance curriculum, and perhaps even on the college campus. Intermediate accounting contains subject matter which requires a higher level of thinking and a greater ability to process prior knowledge than do most other courses the student has been exposed to. Intermediate accounting is also very important for accounting majors as it serves as the basis for much of their future accounting coursework. Obviously, it is of paramount importance that students enter Intermediate Accounting I properly prepared for the course. This research examines the preparation level of Intermediate I students. In particular, this study investigates whether three specific factors relating to the principles of accounting course affect a student's preparation for intermediate accounting. The three factors are: the grade earned in the principles of accounting course, the type of school where the principles of accounting course was taken, and the amount of time that elapsed between the principles course and the intermediate course. This research differs from prior research in this area in that prior research focused on factors affecting performance in intermediate and the current research focus is on preparation for the course. Results of this research include the finding that preparation for intermediate accounting is associated with both the grade earned in principles and the amount of time that elapses between principles and intermediate. While no association is found between the type of school where principles is taken and the level of preparation for intermediate, the results indicate that students who take principles of accounting at a 2-year school are more likely to delay taking intermediate accounting. It appears that students who take principles of accounting at a 2-year school may be less prepared for intermediate, not because of the2-year school per se, but rather because of the associated delay in taking intermediate accounting. These results should be of interest to advisors of future accounting and finance majors, instructors teaching intermediate accounting as well as to individual students planning the timing of their coursework.
\end{abstract}

Keywords: Preparation for Intermediate Accounting; Impact of Principles of Accounting Experience on Intermediate Accounting Performance

\section{INTRODUCTION}

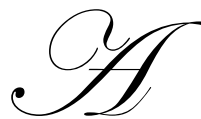

most colleges and universities, accounting and finance students are required to take two intermediate accounting courses to develop a strong foundation of knowledge of financial accounting. Both students and instructors alike will generally agree that intermediate accounting courses are among the most difficult and demanding in an accounting or finance curriculum, and perhaps even on the college campus. Intermediate Accounting I is the first upper level accounting course students take and is often a primary factor in the decision to major (or not major) in accounting. It contains subject matter which requires a higher level of thinking and a greater ability to process prior knowledge than do most other courses the student has been exposed to. Intermediate accounting is also very important for accounting majors as it serves as the basis for much of their future accounting coursework. For all of these reasons, it is of paramount importance that students enter Intermediate Accounting I properly prepared for the course. 
Preparation for intermediate accounting generally occurs in principles of accounting courses which are required as prerequisites for intermediate accounting. In these courses, students are exposed to basic accounting principles and analysis which serve as the foundation for intermediate accounting topics. Thus, if a student does not gain the knowledge provided in the principles courses and retain it, he will enter intermediate accounting courses with a serious deficiency which will make success in intermediate extremely difficult and in many cases impossible. Because adequate preparation for intermediate accounting courses is so important, many schools have added even more requirements for admittance into intermediate accounting courses, such as passing an intermediate entrance exam or a minimum GPA requirement.

The focus of this research is the preparation level of Intermediate I students and how it is affected by three specific factors relating to the accounting principles experience.

\section{PRIOR RESEARCH}

There has been much research on the factors which determine success in intermediate accounting courses. These factors have included cumulative GPA, standardized exam scores such as SAT or ACT, gender, specific course grades, and community college exposure.

Buehlmann and Techavichit (1984), Eskew and Faley (1988), and Doran et al. (1991) found that cumulative GPA was a good predictor of a student's success in accounting principles courses. Burdick and Schwartz (1982) and Hicks and Richardson (1984) found the same to hold true for intermediate accounting courses. Cumulative GPA is a good measure of overall intelligence as well as scholastic abilities such as study skills and habits as well as attitude toward academics. The effects of gender on course performance have not been found to exist once cumulative GPA is controlled for (Tyson, 1989; Buckless et al., 1991; Doran et al. 1991).

However, mastery of accounting principles courses have been found to be a good predictor of intermediate accounting success (Burdick \& Schwartz, 1982; Hicks \& Richardson 1984; and Turner, et.al., 1997). This research also found that students who complete principles at a four year school are more likely to succeed in intermediate accounting than are those students who take principles of accounting at a community college or 2-year school.

All of the research cited above examines the factors that affect performance in intermediate accounting. The current research differs from prior research in that the current research is focused on preparation for, rather than performance in, intermediate accounting. While one would expect a strong association between preparation and performance, they are not, of course, the same thing. There are many other variables besides preparation that could affect performance. Certainly preparation is a key component. However, even a well prepared student may not be successful due to other external variables such as illness, distraction by working too many hours or a new girlfriend, family troubles, etc. Likewise, a poorly prepared student may overcome this handicap with a lot of hard work, tutors, remedial work, etc.

This research attempts to study the preparation level of the student and how the principles of accounting experience affects it. Specifically, this paper focuses on the grade received in the principles course, the type of school where the principles course was taken, and finally, the length of time that has elapsed since the principles course was taken.

\section{STUDY DESCRIPTION}

The current study was conducted at a 4-year public university located in Texas, with an enrollment of approximately 17,000 students. The College of Business at this university is accredited by the AACSB. This study included all students enrolled in Intermediate Accounting I during the fall 2010 and spring 2011 semester, representing a total of 245 students. Students who took the course in both semesters (repeating in the spring) were only included in the survey in the semester they initially took the course (fall). The prerequisites for taking Intermediate Accounting I at this university are completion of both Principles of Accounting I and Principles of Accounting II with at least a $\mathrm{C}$ in each. In addition, all students must have completed at least 60 credit hours before enrolling in Intermediate Accounting I. 
During this academic year, three different faculty members taught this course. These faculty members closely coordinated with each other so that the topics covered, the general approach used and the overall level of difficulty of the course is very similar across sections. There was also a common textbook which was used for all Intermediate I classes during this study period. Thus, concern about the effect of different teachers on students' perception of preparedness is significantly diminished.

\section{Measuring Preparation Levels}

Phase one of this study consisted of developing a measure of how prepared students are for intermediate accounting. Unfortunately, there is no objective way to directly measure how prepared a given student is for intermediate accounting. While one can identify and observe factors which are believed to be related to preparation, one cannot measure preparation directly. Preparation depends not only on the principles of accounting classes taken, but also on how much accounting knowledge the student actually accumulated during those classes, how much they have retained, and the degree to which they have developed the mental analysis skills and overall study habits required for intermediate accounting. This difficulty in objectively measuring preparation is perhaps the reason prior research in this area focused on performance instead of preparation. The current research takes a different approach. This research study asks students themselves, after they have been in an intermediate class, to assess their own level of preparation for that course. Because the student is in the best position to assess how prepared they were when they began the course, this research uses the students themselves as the source of information regarding preparation levels.

Intermediate Accounting I students were surveyed about their perceived preparation for intermediate accounting. The timing of this survey was critical and was carefully selected. If the survey had been administered at the beginning of the intermediate course, student perception of preparation would, in many cases, be inaccurate. It doesn't make sense to ask a student if they were prepared for a course if they haven't had the course yet. In addition, the survey could not be administered at the end of the intermediate course because many of the unsuccessful students would have dropped the course by that time and therefore would not be included in the survey. This was unacceptable as the research design required both successful and unsuccessful intermediate students. Therefore, the intermediate students were surveyed at approximately the midpoint of the semester. Each student had taken at least two exams and had completed about half of the course. This timing ensured that the students who were surveyed had enough experience with intermediate accounting topics to make a realistic assessment about how prepared they were for the course and that the students surveyed included some which would be successful and some which would not.

In the survey, students were asked the following question:

Which of the following best describes your perception of how prepared you were for Intermediate Accounting? (circle one)
a. $\quad$ very well prepared.
b. somewhat prepared.
c. neither prepared nor unprepared.
d. somewhat unprepared.
e. very poorly prepared.

Table 1 shows the number and percentage of students choosing each response.

Table 1

\begin{tabular}{|l|c|c|}
\hline & Frequency & Percent \\
\hline Very Well Prepared & 45 & 18.4 \\
\hline Somewhat Prepared & 125 & 51.0 \\
\hline Neither Prepared nor Unprepared & 37 & 15.1 \\
\hline Somewhat Unprepared & 26 & 10.6 \\
\hline Very Poorly Prepared & 12 & 04.9 \\
\hline \multicolumn{1}{|c|}{ Totals } & 245 & 100.00 \\
\hline
\end{tabular}

(C) 2012 The Clute Institute http://www.cluteinstitute.com/ 
These results were somewhat surprising as only about $16 \%$ of all students surveyed indicate that they felt somewhat unprepared or very poorly prepared for Intermediate. Based on the difficulty level of the course, anecdotal evidence from intermediate accounting instructors, and intermediate accounting failure and drop rates, the expectation was that a higher proportion of students, after completing half the course, would feel that they were not adequately prepared. This result may have been expected if the students had been surveyed at the beginning of the course. But given that they had completed at least half of the course, this was surprising. This result suggests that either the student's perception of their own preparation level or the anecdotal evidence from instructors may be incorrect.

Therefore, the next step was to assess the accuracy of the student's perception of preparation. One would expect that if the student's perception is accurate, and is a good measure of their actual preparation level, it would have a significant association with the student's final course grade. Thus, it was necessary to determine if there was indeed a statistically significant association between the student's perception of preparation and the student's final intermediate accounting grade. The first null hypothesis of this study can be stated as follows:

H10: A student's perceived preparation for Intermediate Accounting I is not associated with the student's final course grade in Intermediate Accounting I.

Table 2a shows the number of students, with each level of preparation, for each grade received.

Table 2a

\begin{tabular}{|l|c|c|c|c|c|}
\hline & \multicolumn{5}{|c|}{ Student Perception of Preparation } \\
\hline Intermediate I Grade & $\begin{array}{c}\text { Very Well } \\
\text { Prepared }\end{array}$ & $\begin{array}{c}\text { Somewhat } \\
\text { Prepared }\end{array}$ & $\begin{array}{c}\text { Neither } \\
\text { Prepared Nor } \\
\text { Unprepared }\end{array}$ & $\begin{array}{c}\text { Somewhat } \\
\text { Prepared }\end{array}$ & $\begin{array}{c}\text { Very Poorly } \\
\text { Prepared }\end{array}$ \\
\hline A & 17 & 15 & 1 & 1 & 0 \\
\hline B & 10 & 31 & 4 & 3 & 0 \\
\hline C & 9 & 40 & 13 & 13 & 4 \\
\hline D & 5 & 22 & 11 & 5 & 3 \\
\hline F & 1 & 7 & 2 & 2 & 2 \\
\hline Drop & 3 & 10 & 6 & 2 & \\
\hline
\end{tabular}

To test for an association between the variables in Table $2 \mathrm{a}$, a chi square test is used. A chi square test is appropriate in this situation because both variables, course grade and preparation level are categorical variables. However, for a valid chi-square result, every cell must have at least 5 observations. Because there are several cells in Table 2a with an insufficient number of observations, it was necessary to redefine the variables before proceeding. The variables can be redefined by grouping the responses in a meaningful way which would then allow for statistical testing.

\section{Redefining Variables}

The responses to the preparation variable were grouped by similar responses to form only two categories of responses. The first category, "Prepared," was formed by grouping together the responses Very Well Prepared and Somewhat Prepared. The remaining three responses were combined into another category, "Unprepared". In addition, the Intermediate I grades were similarly redefined. Intermediate grades of A and B are combined together, the $\mathrm{C}$ grades are left in their own grade category, and grades of D, F and drops are combined into one category. Table $2 \mathrm{~b}$ reflects these newly defined variables.

Table 2b

\begin{tabular}{|c|c|cc|}
\hline & \multicolumn{2}{|c|}{ Preparation } \\
\hline \multicolumn{1}{|c|}{ Intermediate Grade } & \multicolumn{2}{|c|}{ Prepared } & \multicolumn{3}{c|}{ Unprepared } \\
\hline A's \& B's & $73 \quad(58 \%)^{*}$ & $92 \%)$ \\
\hline C's & $49(39 \%)$ & $30(40 \%)$ \\
\hline D's, F's, \& Drops & $48(3 \%)$ & $36(48 \%)^{*}$ \\
\hline \multicolumn{1}{|c|}{ Totals } & $125(100 \%)$ & $75(100 \%)$ \\
\hline
\end{tabular}


The result of the chi-square test on this data is reported below.

\begin{tabular}{|l|c|c|c|}
\hline & Value & df & Significance Level (p-value) \\
\hline Pearson Chi-Square & 22.831 & 2 & .000 \\
\hline
\end{tabular}

The resulting chi-square statistic of 22.831 is significant at the .05 level, which leads to rejection of the null hypothesis of no association. Thus, we can conclude that there is a statistically significant association between the student's reported level of preparation and their final grade in Intermediate Accounting I.

Having determined the existence of an association, the next step was to examine the direction of this association. A pairwise comparison of the columns in Table $2 b$ was completed. In other words, each column was compared to the adjacent column to see if there are statistically significant differences in the proportion of intermediate grades across preparation levels. Again, using a chi-square test, the result of this comparison of column proportions is represented by the asterisks in Table $2 \mathrm{~b}$. An asterisk $\left(^{*}\right)$ in a cell indicates there is a statistically significant higher proportion of students with that grade in that preparation level than in the other preparation level. For example, the * in the upper left corner cell indicates that the prepared students have a statistically higher rate of A's and B's than the unprepared students do. Likewise, the * in the bottom right cell indicates that the unprepared students have a higher proportion of D's, F's and Drops than do the prepared students. The rate of C grades is not statistically different between the prepared and unprepared groups.

These results are exactly what one would expect if student perceptions of their own preparation were accurate. This result lends validity to the use of the student's reported preparation level as a proxy for actual level of preparation. Therefore, throughout the remainder of this study, student perception of preparedness is used as a proxy for actual preparation for Intermediate Accounting I.

\section{Factors Affecting Preparation for Intermediate}

In the second phase of this study, three factors relating to the student's principles experience are examined for an effect on the student's preparation. These include the grade the student received in Principles of Accounting I, the type of school where Principles of Accounting I was taken, and the time elapsed since Principles of Accounting I was taken. Only Principles of Accounting I was used in this study because this course is the financial accounting course at this university as well as at its primary feeder schools. Since intermediate accounting covers only financial accounting topics, the financial principles course would be the most relevant for preparing a student for intermediate accounting.

\section{Principles of Accounting I Grades}

The grade in Principles of Accounting I is a measure of the amount of knowledge acquired in the course. As such we can expect an association between a student's Principles of Accounting I grade and the student's preparation level. The related null hypothesis can be stated as follows:

Ho2: There is no association between Principles of Accounting I grade and preparation for Intermediate Accounting I.

Table 3 shows the number of students receiving each Principles of Accounting I grade at each level of preparation.

Table 3

\begin{tabular}{|l|c|cc|}
\hline & \multicolumn{3}{|c|}{ Preparation } \\
\hline Principles I Grade & \multicolumn{2}{|c|}{ Prepared } & \multicolumn{2}{c|}{ Unprepared } \\
\hline A & $96(56.5 \%)^{*}$ & \multicolumn{2}{c|}{$(25.3 \%)$} \\
\hline B & $51(30 \%)$ & 37 & $(49.3 \%)^{*}$ \\
\hline C & $23(13.5 \%)$ & $19(25.3 \%)^{*}$ \\
\hline
\end{tabular}


Chi-Square Test of Table 3

\begin{tabular}{|l|c|c|c|}
\hline & Value & df & Significance Level (p-value) \\
\hline Pearson Chi-Square & 20.524 & 3 & .000 \\
\hline
\end{tabular}

The significant chi-square value indicates that there is a significant association between the principles of accounting I grade and the level of preparation for intermediate, leading us to reject the null hypothesis. As before, a test of column proportions was also performed to check on the direction of this association. The results are again indicated by the asterisks in Table 3. The direction of the association is as expected. The asterisk in the prepared column of Table 3 indicates that the percentage of students getting A's is statistically higher among prepared students $(56.5 \%)$ than it is among unprepared students $(25.3 \%)$. Likewise, the asterisks in the unprepared column indicate that a statistically higher proportion of the unprepared students get B's and C's than do the prepared students. While it is not surprising that unprepared students get more C's, it is interesting to note that they also get more B's.

\section{Type of School}

The next factor which may affect a student's preparation for intermediate accounting is the type of school where the student took their Principles of Accounting I course. Prior research found that taking the principles course at a 2-year institution was negatively associated with performance in intermediate. In addition, anecdotal evidence from intermediate instructors also suggests that students who have taken principles at a 2-year school seem to have a disadvantage in intermediate accounting. Therefore, the current research asks the question: Does the type of school where a student took principles of accounting affect how prepared they will be for intermediate accounting? The null hypothesis can be stated as follows:

Ho3: There is no association between the type of school where a student takes Principles of Accounting I and the student's level of preparation for Intermediate Accounting I.

Table 4 presents the number (and percentage) of students who took principles of accounting I at each type of institution, for each level of preparation.

Table 4

\begin{tabular}{|c|c|cc|}
\hline & \multicolumn{2}{|c|}{ Preparation } \\
\hline School Type & Prepared & \multicolumn{2}{c|}{ Unprepared } \\
\hline 2-year & $77(45.3 \%)$ & 38 & $(50.7 \%)$ \\
\hline 4-year & $93(54.7 \%)$ & 37 & $(49.3 \%)$ \\
\hline
\end{tabular}

Chi-Square Test of Table 4

\begin{tabular}{|l|c|c|c|}
\hline & Value & df & Significance Level (p-value) \\
\hline Pearson Chi-Square & .603 & 1 & .437 \\
\hline
\end{tabular}

The resulting chi-square statistic of .603 is not significant at the .05 level, which indicates that there is no significant association between the student's reported level of preparation and the type of school where they took Principles of Accounting I. Thus, we are unable to reject H3o, the null hypothesis of no association. This is a very interesting result because it is not consistent with prior research or the general impression of intermediate accounting instructors at this university.

\section{Elapsed Time}

The third factor which may affect a student's preparation for intermediate is the length of time that has elapsed since they took Principles of Accounting I. It would be expected that the greater the amount of time elapsed, the less prepared the student would be. The resulting fourth null hypothesis is: 
Ho4: There is no association between the time elapsed since taking Principles of Accounting I and the level of preparation for Intermediate Accounting I.

To investigate this association, students were placed into three groups according to elapsed time since they took Principles of Accounting I. The groups are as follows:

- $\quad$ Less than or equal to 1 year (the traditional expected timing)

- $\quad$ Greater than 1 year but less than or equal to 2 years

- $\quad$ Greater than 2 years.

It is expected that a student's preparation for intermediate accounting will be greater the more recently they have taken the prerequisite principles course. Table 5 presents the number of students in each elapsed time group by preparation level.

Table 5

\begin{tabular}{|l|c|c|}
\hline & \multicolumn{2}{|c|}{ Preparation } \\
\hline Elapsed Time Since Principles I & Prepared & \multicolumn{2}{|c|}{ Unprepared } \\
\hline$\leq$ 1 year & $69(40.6 \%)^{*}$ & 14 \\
\hline$>$ 1 and $\leq$ 2 years & $57(33.5 \%)$ & $26.7 \%)$ \\
\hline$>$ 2 years & $44(25.9 \%)$ & $35.7 \%)$ \\
\hline
\end{tabular}

Chi-Square Test of Table 5

\begin{tabular}{|l|c|c|c|}
\hline & Value & df & Significance Level (p-value) \\
\hline Pearson Chi-Square & 14.374 & 2 & $.001^{*}$ \\
\hline
\end{tabular}

The chi-square statistic of 14.374 is significant at the .05 level, which indicates that there is a statistically significant association between the student's level of preparation and the time that has elapsed since they took Principles of Accounting I. Thus, we are able to reject Ho4, the null hypothesis of no association. This result is consistent with expectations. The longer it has been since a student learned the basics of accounting, the more likely it is that they have forgotten important material and therefore are less prepared. The asterisks in Table 5 indicate that the percentage of prepared students who take intermediate I in one year or less (40.6\%) is statistically higher than the percentage of unprepared students who take intermediate within that same time frame (18.7\%). Likewise, the percentage of unprepared students who wait the longest to take intermediate (46.6\%) is statistically higher than the percentage of prepared students who wait that long $(25.9 \%)$.

\section{Association between the three principles of accounting course factors}

Finally, the association between principles grade, type of school and elapsed time was examined. Two by two chi-square tests were used. No association was found between elapsed time and grade or school type and grade. The only statistically significant association found between these three variables was between elapsed time and school type. Table 6 below shows the data for these variables.

Table 6

\begin{tabular}{|c|c|c|}
\hline & \multicolumn{2}{|c|}{ School Type } \\
\hline Time Elapsed & 2-year & 4-year \\
\hline$<1$ year & $20 \quad(17.4 \%)$ & $63 \quad(48.5 \%)^{*}$ \\
\hline$>1$ and $\leq 2$ years & $39 \quad(33.9 \%)$ & $44 \quad(33.8 \%)$ \\
\hline$>2$ years & $56 \quad(48.7 \%)^{*}$ & $23 \quad(17.7 \%)$ \\
\hline
\end{tabular}

Chi-Square Test of Table 6

\begin{tabular}{|l|c|c|c|}
\hline & Value & df & Significance Level (p-value) \\
\hline Pearson Chi-Square & 35.578 & 2 & $.000^{*}$ \\
\hline
\end{tabular}


The asterisks indicate that the percentage of students taking Intermediate I within 1 year of taking Principles I (48.5\%) is significantly higher among students taking principles at a 4-year school than it is among 2year school students (17.4\%). In addition, the percentage of students waiting more than 2 years to take Intermediate I (48.7\%) is significantly higher among students who take principles at a 2-year school than at a 4-year school $(17.7 \%)$. This is a very important result. Students who take principles I at a 2-year school are more likely to delay taking Intermediate I. The reasons for this delay are most likely the same reasons the student chose a 2-year school in the first place such as financial needs and the need or desire to remain close to family. This result is important because of the earlier result which established that delaying intermediate can result in being less prepared. This result is very important when advising students at 2-year institutions who plan to transfer to a 4-year school.

\section{SUMMARY AND INTERPRETATION OF RESULTS}

This study was unique in that it focused on preparation for intermediate accounting, rather than on performance. Results indicate that the higher the grade a student earns in Principles of Accounting I, the more prepared a student will be for Intermediate Accounting I. In addition, this study found that the greater the delay in taking intermediate, the less prepared the student will be. These results are consistent with expectations since the principles grade is associated with the quantity of knowledge acquired in principles and the elapsed time is associated with retention of principles knowledge. Both the quantity of knowledge acquired and the amount retained are primary components of preparedness.

A surprising finding of this study was the lack of association between type of school and preparedness. Anecdotal evidence from intermediate accounting instructors would suggest that students from two year schools seem to be less prepared. In addition, prior research indicated lower performance for students from 2-year schools. It is often assumed that this is because students taking principles at a 2-year school acquire less accounting knowledge due to a difference in the level of rigor or material covered in the principles course. However, the results of this study indicate that the type of school is not a factor in a student's preparation for Intermediate I.

This evidence is even more interesting in light of the additional finding of this research that there is a strong positive association between the type of school and the amount of time that elapsed between principles and intermediate. Students who take principles of accounting at a 2-year school are more likely to delay taking Intermediate I for over two years. This is most likely the reason that many intermediate accounting instructors perceive 2-year students as relatively less prepared. While it is true that these students are often less prepared, it may not be because they acquired less knowledge when taking principles at a 2-year school, but rather because they did not retain as much of the knowledge due to the associated long delay in taking intermediate accounting. These results should be of interest to advisors, particularly of students who are transferring from a 2-year school. Students in principles of accounting classes should be advised as to the importance of taking intermediate accounting as soon as possible to maximize their potential success in that course.

\section{AUTHOR INFORMATION}

Linda G. Carrington is an Associate Professor of Accounting at Sam Houston State University in Huntsville, Texas. She received her Ph.D. from the University of Maryland, an MBA from the University of Kentucky, and a BBA in Accounting from Eastern Kentucky University. Dr. Carrington is a Certified Public Accountant, licensed in Kentucky. Dr. Carrington teaches financial accounting courses and her research interests include financial accounting topics as well as accounting education. E-mail: AAC_LGD@shsu.edu

\section{REFERENCES}

1. Buehlmann, D.M., Techavichit, J.V. (1984). "Factors Influencing Final Examination Performance in Large Versus Small Sections of Accounting Principles." Journal of Accounting Education, 2(1), 127-136.

2. Burdick, R., Schwartz, B.N. (1982). "Predicting Grade Performance for Intermediate Accounting." Delta Pi Epsilon Journal, 117-127.

3. Doran, B.M., Bouillion, M.L., Smith, C.G. (1991). "Determinants of Student Performance in Accounting Principles I and II." Issues in Accounting Education, 6(1), 74-84. 
4. $\quad$ Eskew, R.K., Faley, R.H. (1988). "Some Determinants of Student Performance in the First College-Level Financial Accounting Course." The Accounting Review, 63(1), 137-147.

5. Hicks D.W., Richardson, F.M. (1984). "Predicting Early Success in Intermediate Accounting: the Influence of Entrance Examination and GPA." Issues in Accounting Education, 61-67.

6. Turner, J.L., Holmes, S.A., and Wiggins, C.E. (1997). "Factors Associated With Grades in Intermediate Accounting." Journal of Accounting Education, 15(2), 269-288.

7. Tyson, T. (1989). "Grade Performance in Introductory Accounting Courses: Why Female Students Outperform Males." Issues in Accounting Education, 4(1), 153-160. 
NOTES 